\title{
Economics of cowpea production under small-scale cowpea enterprise in Agricultural Zone I of Niger State, Nigeria.
}

\author{
A.Abdullahi ${ }^{1 *}$ and M. Tsowa ${ }^{2}$ \\ Department of Agricultural Economics and Extension Technology, Federal University of Technology., Minna, \\ Nigeria \\ Niger State House of Assembly, Minna, Nigeria
}

\begin{abstract}
This paper analyses the economics of small-scale cowpea farmers in agricultural zone lof Niger State. A sample of 158 farm households selected using simple random sampling technique were used to generate primary data. Results show that most (87\%) of the farmers were male and within the active age of 20 and above. About $47 \%$ of them had no formal education, while $53 \%$ have one form of education or the other. The average farm size was $2.8 \mathrm{ha}$ while the average yield was $5,041.47 \mathrm{~kg} / \mathrm{ha}$. The average variable cost, average fixed cost and average net farm income per hectare were $\$ 28,839.30, \$ 3,160.45$ and $\$ 30,463.10$, respectively. The results of production function analysis revealed that, farm size, labour, agro-chemical and capital were important in explaining the variation in output of cowpea production in the study area. Pests and diseases, nonpassable roads and inadequate finance were the major problems militating against cowpea production. Based on these findings, it can be concluded that, the study area had great potential to increase cowpea production and farmer's income, if efforts are made for the widespread adoption of new technologies and identified constraints are addressed. However, effort should be made to mobilize and encourage farmers to form cooperatives so that they can pool their resources together to increase their scale of operation. Also government should make production inputs like improved seeds and agro-chemicals available to farmers at the right time at subsidized rates because production inputs were some of the important limiting resources that adversely affected cowpea production in the study area.
\end{abstract}

\section{Introduction}

Agriculture is a major sector of Nigeria's economy, it provides food and processed products for the populace as well as raw materials for agro-allied industries (Odebode, 2007). Adesina (1991) reported that the role of agriculture is to provide adequate output to ensure global food security and enhance economic development, nevertheless agricultural development in Nigeria has suffered a lot of setback due to the shift of emphasis and manpower development to petroleum sector. However, to ensure food sufficiency, priority must be given to small holder farmers who constitute about $95 \%$ of farming household in Nigeria and produced most of the food crops consumed in the country.

According to Gulati (2000), Nigeria from 1970's has witnessed a considerable decline in food production and a widening gap in the supply - demand which is brought about by a high population growth of $3.5 \%$ per annum relative to food production growth of about $1.5 \%$ per annum. This problem is attributed to rapid urbanization, low per capita income, poor storage, inadequate transportation and poor marketing facilities as well as shift of emphasis from agricultural sector to the oil sector of the national economy and the non challeant attitude to agriculture by the farmers. Khan (2002) stressed that Nigeria's agricultural production is much lower than many other countries of the world, and that there is a big gap between actual yield and attainable potential yield of crops. Different categories of food substance are needed for human existence, such as carbohydrate and protein. Cowpea is one of the cheapest non- animal protein sources of food that is required for proper human growth.

Cowpea (vigna unguiculata) (L) walp) is a native of tropical Africa and is one of the most important legume in the world. It is also the most widely distributed crop, occupying double the area of any other crop. Cowpea is a legume that is extensively grown throughout the sub-Saharan Africa. It is a subsistence crop often intercropped with sorghum, maize and millet. Cowpea is cultivated for its leaves green pods, grains stover and mature pods. The young leaves and immature pods are used as vegetables while snacks and main dishes are prepared from grains, as it is one of the cheapest sources of plant protein to a majority of people in Nigeria. Cowpea has great potential and can play a crucial role in contributing to food and nutritional security and poverty reduction, income generation and socio-economic growth of West Africa (Nigeria in particular). The demand for cowpea in Nigeria and other parts of West Africa is increasing because of high population growth from Urban Centers and also because of poverty and the demand for low-cost food. Nigeria is the largest producer and consumer of cowpea in West Africa and the world at large, accounting for over two million metric tons which is about 50\% of the world output and 53\% of production in Africa, yet Nigeria with high population 
growth rate imports cowpea from neighboring countries (Singh.,Ehlers., Sharma., Freire, Filho, 2002 and FAOSTAT, 2006; FAO, 2011).

FAOSTAT (2000), reported that the world cowpea production was estimated at 3,319,375 MT and $75 \%$ of that production is from Africa. The principal cowpea producing countries in West Africa are Nigeria, Niger, Senegal, Ghana, Mali and Burkina Faso. However, among these countries, Nigeria and Niger are the leading producers accounting for 2,099,000 and 641,000MT respectively in 1999. Nigeria with a population of over 140, million people is the largest producer of cowpea in West Africa, also has the highest level of consumption with a per capita consumption of $23 \mathrm{~kg}$ per year with the domestic deficit of 518,400MT per year. This deficit is partly met by importation from neighboring countries like Niger.

Cowpea is a very important crop grown in many parts of Nigeria. It provides protein to rural as well as urban dwellers as a substitute for the animal protein. Production is primarily by small scale farmers with average farm sizes of 2-4 hectares. Average yield of cowpea in Nigeria is 417kg per hectare. (Singh et al, 2002). This is yield is below an achievable yield of between 1500-3000kg/ha (Dzemo.,Niba and Asiwe, 2010). This is also low when compared with $2,666 \mathrm{~kg} / \mathrm{ha}$ and $687 \mathrm{~kg} / \mathrm{ha}$ obtained in place like Egypt and Malawi respectively (FAOSTAT, 2010). This notwithstanding, Nigeria lags far behind in its ability to grow enough food to feed its ever increasing population. This revealed that Nigeria is not food secured and food insecurity is the most profound physical expression of absolute poverty (World Bank, 1992; FAOSTAT, 2000). Fasasi (2007) reported that despite increasing land area been put in to food production; Nigeria has not been able to attain selfsufficiency in food production. One way small-scale farmers can achieve sustainable agricultural development is to raise the productivity of their farm by improving efficiency within the limits of the existing resource base and available technology. In the same vein, Harwood (1987) was of the opinion that efficient use of various inputs is an important part of sustainability which implies either fewer inputs to produce the same level of output or higher output at the same level of inputs. An increase in efficiency in food crop production could invariably lead consequently to a reduction in the welfare of farmers and consequently a reduction in their poverty level and food insecurity.

The limited capacity of the Nigeria cowpea sector to meet the domestic demand has raised a number of pertinent questions both in policy circles and among researchers. Some of these questions have to do with whether farmers are allocating resources efficiently in cowpea production or whether they are receiving remunerative profits in cowpea production.

In this study, therefore, an attempt has been made to examine the economics of cowpea production under smallscale cowpea enterprise in Agricultural Zone I of Niger State. The specific objectives are to:

i. describe the personal and socio-economic characteristics of sampled farmers in the area;

ii. evaluate the level of resource use among small-scale cowpea farmers in the study area;

iii. determine the profitability of small-scale cowpea production in the study area.

iv. examine the factors that affect profitability of cowpea production;

v. determine the technical relationship between input and output realized in cowpea production and

vi. determine the resource use efficiency in cowpea production in the studies area.

\section{Methodology}

The study was conducted in 2013 cropping season in selected Local Government Areas in agricultural zone1 of Niger State. The State is located in the Guinea Savanna vegetation zone in the north central part of Nigeria between latitudes $3^{\circ} 20-7^{\circ} 4^{\prime} \mathrm{N}$ and longitude $8^{\circ}-11^{\circ} 3^{\prime} \mathrm{E}$. The area receives an annual rainfall of $1,200 \mathrm{~mm}$ which is steady and is evenly distributed falling usually between mid April and November, peaking in August with the average monthly temperature ranging from $23^{\circ} \mathrm{C}$ to $37^{\circ} \mathrm{C}$ (NSADP, 2012). Niger State covers a land area of 92,800 square kilometers which is about $10 \%$ of the total land area of Nigeria. About $85 \%$ of this land area is arable. Niger State has a population of three million nine hundred and fifty thousand two hundred and forty nine people $(3,950,249)$ (NPC, 2006). The State is endowed with fadama lands found along the plains of the River Kaduna and River Niger (NSADP, 2006). The State has large area of Fadama and fertile arable land, which support cowpea production. Farming is the primary occupation of 85 percent of the State's population. However, agriculture in Niger State is predominantly in the hands of rural dwellers who work small holdings. It has been estimated that there are over 100,000 farm families in the State. The major crops grown include cowpea, sugar cane, maize, millet, melon, rice, yam, groundnut, sorghum and cowpea (NSADP, 1999).

Sampling Procedure: In order to obtain a representative sample, a total of 158 cowpea farmers were sampled from three purposively selected local government areas (LGAs) in agricultural zone 1 of Niger State, including Edati, Lavun and mokwa. This is because of high concentration of cowpea farmers in these LGAs. From each LGA, two districts were randomly selected and from each district five villages were selected. In each village, simple random sampling technique was used in the selection ten and eleven farm families. Data were collected on levels of inputs and output, their prices and socio-economic characteristics of the farmers. 
Data Collection: Data collected for the study was achieved by the use of a well-structured questionnaire administered to the respondents and complemented with personal interview.Data collected on the socioeconomic characteristic of the farmers, farm size (ha), quantity of cowpea seed (kg), labour (man-day) herbicides (litre) and output $(\mathrm{kg})$ realized

Analytical Techniques: Collected data were analyzed using descriptive statistics, farm budgeting techniques, Multiple regression analysis and as well as production function analysis.

Descriptive Statistics: Descriptive statistic such as tabulations, means, frequency distribution and percentages were used to analyzed the socio-economic characteristics of the farmers, evaluate the level of resource use among farmers and identify the problems associated with cowpea farmers.

Farm Budgeting Model: Farm Budgeting Tool was used to analyzed the profitability of cowpea production. The farm budgeting tool is widely used in farm management and production economics studies. The farm budgeting tool is an operation leading to the determination of cost and revenue for a given production period (Olayide and Heady, 1982). GM is expressed as:

$\mathrm{GM}=\mathrm{TR}-\mathrm{TVC}$

$\mathrm{TR}=$ Quantity of output $\left(\mathrm{Q}_{\mathrm{i}}\right) \mathrm{X}$ price $\left(\mathrm{P}_{\mathrm{i}}\right)$

TVC $=$ Quantity of input $\left(\mathrm{X}_{\mathrm{j}}\right) \mathrm{X}$ price $\left(\mathrm{P}_{\mathrm{j}}\right)$

$\mathrm{GM}=\sum \mathrm{P}_{\mathrm{i}} \mathrm{Q}_{\mathrm{i}}-\sum \mathrm{P}_{\mathrm{j}} \mathrm{X}_{\mathrm{j}}$

$\mathrm{i}=1 \quad \mathrm{j}=1$

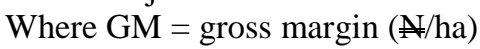

$P_{i}=$ average price of output $\mathrm{i}(\mathrm{N} / \mathrm{kg})$

$\mathrm{Q}_{\mathrm{i}}=$ average quantity of output $\mathrm{j}(\mathrm{kg} / \mathrm{ha})$

$P_{j}=$ average price of input $\mathrm{j}(\AA / \mathrm{kg})$

$\mathrm{X}_{\mathrm{j}}=$ quantity of input $\mathrm{j}$ used $(\mathrm{kg} / \mathrm{ha})$

$\underset{\mathrm{i}=1}{\mathrm{GM}}=\sum \mathrm{P}_{\mathrm{i}} \mathrm{Q}_{\mathrm{i}}-\sum \mathrm{P}_{\mathrm{j}} \mathrm{X}_{\mathrm{j}}$

Where $i$ is the number of observations ( $i=1,2,3,4,----158)$

$\mathrm{P}_{\mathrm{i}} \mathrm{Q}_{\mathrm{i}}=\mathrm{Pc}_{\mathrm{i}} \mathrm{Qc}_{\mathrm{i}}$

$\mathrm{Pc}_{\mathrm{i}}=$ average price of cowpea sold ( $\# /$ ha)

$\mathrm{Qc}_{\mathrm{i}}=$ average quantity of cowpea sold $(\mathrm{kg} / \mathrm{ha})$

$\mathrm{P}_{\mathrm{j}} \mathrm{X}_{\mathrm{j}}=\mathrm{Cc}_{\mathrm{j}} \mathrm{Qc}_{\mathrm{j}}+\mathrm{L}_{\mathrm{j}}+\mathrm{Cf}_{\mathrm{j}}+\mathrm{Qf}_{\mathrm{j}}+\mathrm{Ca}_{\mathrm{j}}+\mathrm{Qa}_{\mathrm{j}}$

$\mathrm{Cc}_{\mathrm{j}}=$ average cost of cowpea seed used for planting $(\mathrm{N} / \mathrm{kg})$

$\mathrm{Qc}_{\mathrm{j}}=$ average quantity of cowpea seed used for planting $(\mathrm{kg} / \mathrm{ha}) \backslash$

$\mathrm{L}_{\mathrm{j}}=$ average cost of labour used for all farm operation ( $)$

$\mathrm{Ca}_{\mathrm{j}}=$ average cost of agrochemicals used ( $\# /$ litre)

$\mathrm{Qa}_{\mathrm{j}}=$ average quantity of agrochemicals used ( litre/ha)

Gross Ratio: This is a profitability ratio that measures the overall success of the farm and the Lower the ratio, the higher the return per naira.

$$
\mathrm{GR}=\underline{\mathrm{TFE}}
$$

where GR $=$ Gross Ratio, TFE $=$ Total Farm Expenses and GI = Gross Income.

Operating Ratio: The operating ratio is directly related to the farm variable input usage. The lower the ratio, the higher the profitability of the farm business.

$\mathrm{OR}=\mathrm{TOC}$

GI

Where $\mathrm{OR}=$ operating Ratio, $\mathrm{TOC}=$ Total Operating Cost and GI $=$ Gross Income.

Return on Capital Invested: This is defined as gross margin divided by total variable cost.

$\mathrm{RI}=\underline{\mathrm{GM}}$

TVC

Where RI = Return on Capital Invested, GM = Gross Margin, and TVC = Total Variable Cost. 
Multiple Regression Model: Multiple Regression Analysis was used to analysed factors affecting the profitability of cowpea production. Regression is the general process of predicting one variable from another by statistical means using previous data (Levin, 1984).

Mathematically the model for this study is specified in general form as:

$\mathrm{Y}=\mathrm{F}\left(\mathrm{X}_{1}, \mathrm{X}_{2}, \mathrm{X}_{3}, \mathrm{X}_{4}, \mathrm{X}_{5} \mathrm{X}_{6}, \mathrm{X}_{7}, \mathrm{X}_{8}, \mathrm{X}_{9}, \mathrm{X}_{10}\right)$

Where,

$$
\begin{aligned}
& \mathrm{Y}=\text { Profit }(\AA) \text {, } \\
& \mathrm{X}_{1}=\text { Farm size (ha), }
\end{aligned}
$$

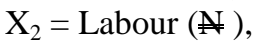

$$
\begin{aligned}
& \mathrm{X}_{3}=\text { Capital ( }(\text { ), } \\
& \mathrm{X}_{4}=\text { Fertilizer }(\mathbb{N}) \text {, } \\
& \mathrm{X}_{5}=\text { Seed (N) }
\end{aligned}
$$

The functional forms of the model estimated are specified as follows

Linear Function

$$
\begin{aligned}
& Y=a+b_{1} X_{1}+b_{2} X_{2}+b_{3} X_{3}+b_{4} X_{4}+b_{5} X_{5}+b_{6} X_{6}+b_{7} X_{7}+b_{8} X_{4} 8+b_{9} X_{9}+b_{10} X_{10}+e----(10) \\
& \text { Semi }-\log \text { Function } \\
& Y=a+b_{1} \log X_{1}+b_{2} \log X_{2}+b_{3} \log X_{3}+b_{4} \log X_{4}+b_{5} \log X_{5}+b_{6} \log X_{6}+b_{7} \log X_{7}+b_{8} \log X_{8}+b_{9} \log X_{9}+b_{10} \log X_{10}+e-- \\
& \text { Quadratic Function } \\
& Y=a+b_{1} X_{1}+b_{2} X_{2}+b_{3} X_{3}+b_{4} X_{4}+b_{5} X_{5}+b_{6} X_{6}+b_{7} X^{2}{ }_{7}+b_{8} X+b_{9} X_{2}^{2}+b_{10} X^{2}{ }_{3}+b_{11} X_{4}^{2}+b_{12} X^{2}+e .
\end{aligned}
$$

Cobb-Douglas model 2

$\log Y=\log a+b_{1} \log X_{1}+b_{2} \log X_{2}+b_{3} \log X_{3}+b_{4} \log X_{4}+b_{5} \log X_{5}+b_{6} \log X_{6}+e$

Where

$\mathrm{a}=$ intercept

$\mathrm{b}_{1}-\mathrm{b}_{6}=$ regression coefficients estimated

$\mathrm{e}=$ Error term

Production Function Analysis: Production function model was used to analyzed the technical relationship between input and output of cowpea realized. For the analysis, the linear function, semi-log, quadratic and cobDouglass will be tried and a lead equation will be chosen base on economic criterion.

Mathematically the model for this study is specified in general forms as: -

$\mathrm{Y}=\mathrm{F}\left(\mathrm{X}_{1}, \mathrm{X}_{2}, \mathrm{X}_{3}, \mathrm{X}_{4}, \mathrm{X}_{5}\right)$

Where

$\mathrm{Y}=$ Yield of cowpea $(\mathrm{kg})$

$\mathrm{X}_{1}=$ Farm Size (ha)

$\mathrm{X}_{2}=$ Quantity of seed $(\mathrm{kg})$

$\mathrm{X}_{3}=$ Capital $(\aleph)$

$\mathrm{X}_{4}=$ labour (Man-days)

$\mathrm{X}_{5}=$ Agro-chemicals (Litres)

$\mathrm{U}=$ Error term

The functional form of the model are specified as follows:

$$
\begin{aligned}
& \mathrm{Y}=\mathrm{a}+\mathrm{b}_{1} \mathrm{X}_{1}+\mathrm{b}_{2} \mathrm{X}_{2}+\mathrm{b}_{3} \mathrm{X}_{3}+\mathrm{b}_{4} \mathrm{X}_{4}+\mathrm{b}_{5} \mathrm{X}_{5}+\mathrm{b}_{6} \mathrm{X}_{6}+\mathrm{b}_{7} \mathrm{X}_{7}+\mathrm{U}_{\mathrm{i}} \text { (Linear) } \\
& \mathrm{Y}=\mathrm{a}+\mathrm{b}_{1} \ln \mathrm{X}_{1}+\mathrm{b}_{2} \operatorname{In} \mathrm{X}_{2}+\mathrm{b}_{3} \operatorname{In} \mathrm{X}_{3}+\mathrm{b}_{4} \operatorname{In} \mathrm{X}_{4}+\mathrm{b}_{5} \operatorname{In} \mathrm{X}_{5}+\mathrm{b}_{6} \operatorname{In} \mathrm{X}_{6}+\mathrm{b}_{7} \operatorname{In} \mathrm{X}_{7}+\mathrm{U}_{\mathrm{i}}(\text { Semi-log }) \\
& \operatorname{InY}=a+b_{1} \operatorname{In} X_{1}+b_{2} \operatorname{In} X_{2}+b_{3} \operatorname{In} X_{3}+b_{4} \operatorname{In} X_{4}+b_{5} \operatorname{In} X_{5}+b_{6} \operatorname{In} X_{6}+b_{7} \operatorname{In} X_{7}+U_{i}(\text { double log }) \\
& \mathrm{Y}=\mathrm{a}+\mathrm{b}_{1} \mathrm{X}_{1}+\mathrm{b}_{2} \mathrm{X}_{2}+\mathrm{b}_{3} \mathrm{X}_{3}+\mathrm{b}_{4} \mathrm{X}_{4}+\mathrm{b}_{5} \mathrm{X}_{5}+\mathrm{b}_{6} \mathrm{X}_{6}+\mathrm{b}_{7} \mathrm{X}_{7}{ }^{2}+\mathrm{b}_{8} \mathrm{X}_{2}+\mathrm{b}_{9} \mathrm{X}_{2}{ }_{2}+\mathrm{b}_{10} \mathrm{X}_{3}{ }^{2}+\mathrm{b}_{11} \mathrm{X}_{4}{ }^{2}+\mathrm{b}_{12} \mathrm{X}_{5}{ }^{2}+\mathrm{U}_{\mathrm{i}}
\end{aligned}
$$

Resource use efficiency was computed as follows:-

$\underline{\mathrm{MVP}}=\mathrm{r}$

MFC

Where:

$r=$ efficiency ratio.

If $\quad r=1$, efficient utilization

$r>1$, under utilization

$r<1$, over utilization of resource

MVP $=$ Marginal value product

MFC $=$ Marginal factor cost 


\section{Socio-Economic Characteristics of the respondents}

\section{Results and Discussion}

Several indicators were used in this study to identify the socio-economic status of cowpea farmers in the study area. The variable analysed in this study include age, marital status, mode of land acquisition, years of farming experience, level of education and household size .Table 1 revealed that $81.70 \%$ of the sampled farmers were within the age bracket of 21-50 years. This reveals that majority of the sampled farmers were of middle age. This implies that the farmers are still in their economically active age, which could result in a positive effect on production, and because cowpea production is surrounded by risks and uncertainties, such as theft, diseases and pests among others, it therefore requires people who are able and willing to take risks in expectation of profit. The result agrees with the findings of Obeta and Nwagbo (1999) who noted that younger farmers are more amenable to new ideas and risk; they are expected to adopt innovation more readily than older ones.

About $53.80 \%$ of the sampled farmers had one form of formal education or the other. Njoku (1991) and Roger and Shoemaker (2001) in their separate study observed that education is not only an important determinant of adoption of innovations but also an instrument for successful implementation of innovation for profitability. They also stressed that farmers who have attained some level of formal education are likely to raise their productivity through wise use of credit. Furthermore, over $82 \%$ of the respondents acquired their land through inheritance. The remaining $13 \%$ was either through, rent or borrowing. It would appear that dependence mainly on inheritance has caused fragmentation of land holdings. As majority (87\%) of the respondents in the study area owned between two to four plots. The system of land tenure by inheritance encourages fragmentation and sub-division of land holdings. The principal economic effect of this, as reported by Araka (1990), is a potential reduction of efficiency of labour due to movement from one plot to another. Also, land improvement and conservation may be hampered owing to the need for cooperation among neighbours. Fragmented small holdings also deny the farmers benefits of scale economies. Similarly, most (94.50\%) of the farm families had been in cowpea farming for 6 years and above. The years of farming experience had a direct relationship with the age of the household head. Their long years of farming experience will enable them to overcome constraints faced in cowpea production and this also depicts good signal for high productivity. Also, about 93 percent of the respondents in the study area were married couples, and this is an indication of their chances of getting family labour for use on their cowpea farms. The respondents in the study area had family sizes ranging from 1-20 with mean of 9 . The implication is that farmers with large family size will however; also need to increase their productivity to meet up with the consumption need of the family. The implication of the large family size in the area is that family expenditure tends to draw more on family income so that only a meager sum is saved and invested eventually in farming. However, the large family size may imply a probable greater farm output for the farmers.

Table 1 : Socio-economic characteristics of the cowpea farmers

\begin{tabular}{lcc}
\hline Variables & Frequency & Percentage \\
\hline Age in year & 29 & 18.40 \\
$21-30$ & 49 & 31.00 \\
$31-40$ & 51 & 32.30 \\
$41-50$ & 29 & 18.40 \\
Over 50 & & 01.30 \\
Level of education & 02 & 1.90 \\
Adult & 03 & 25.30 \\
Primary & 40 & 28.50 \\
Secondary & 45 & 43.00 \\
Tertiary & 68 & 82.30 \\
Non-formal & & 07.60 \\
Mode of land acquisition & 130 & 10.10 \\
Inheritance & 11 & \\
Rented & 16 & \\
Community owned & & \\
\hline
\end{tabular}




$\begin{array}{lcc}\text { Year of farming experience } & 08 & 05.70 \\ 1-5 & 07 & 04.40 \\ 6-10 & 90 & 57.00 \\ 11-15 & 53 & 33.60 \\ \text { Over } 15 & & \\ \text { Marital status } & 149 & 94.30 \\ \text { Married } & 09 & 05.70 \\ \text { Single } & & \\ \text { Family size } & 49 & 31.00 \\ 1-5 & 71 & 44.90 \\ 6-10 & 35 & 22.20 \\ 11-15 & 03 & 01.90 \\ \text { Over } 15 & \mathbf{1 5 8} & \mathbf{1 0 0 . 0 0} \\ \text { Total } & & \end{array}$

Source: Field survey, 2013.

\section{Level of Resource Use \\ Land}

The distribution of respondents based on the size of their farm holding is shown in Table 2. which shows that majority $(94.31 \%)$ of the farm family in the study area had small farm holdings of 2.5 ha or less. The size of farm determines the extent to which other resources (capital, labour etc) are used for optimum productivity. According to Alamu et al. (2002), farmers with more resources including land area are more likely to take advantage of a new technology. The analysis of land use reveals that a total of 342 ha were cultivated by all the respondents and individual plot sizes ranged from 0.10 ha to 4 ha with a mean of 1.80 ha. This indicates that majority of the farmers in the study area were small holders. This situation where many farmers cultivated only small plots of land will not promote agricultural production beyond subsistence level.

Table 2 Distribution of respondents according to farm size.

\begin{tabular}{lcc}
\hline Farm size(Ha) & Frequency & Percentage \\
\hline $0.1-1.5$ & 102 & 64.56 \\
$1.6-2.5$ & 47 & 29.75 \\
$2.6-3.5$ & 06 & 03.80 \\
$3.5-4.5$ & 03 & 01.89 \\
\hline Total & 158 & 100.00 \\
\hline
\end{tabular}

Source: Field survey, 2013

\section{Labour Utilization in Cowpea Production.}

Farmers in the study area utilized both family and hired labour. The level of labour input use according to farm operations presented in Table 3 reveals that a total of 945.41 manday/ha of labour was used. Family labour use was most prevalent in the area, accounting for over $78.94 \%$ of the total labour used, while hired labour accounted for $21.06 \%$ of total labour requirement. However, the fact that up to $21.06 \%$ of labour input was hired, shows the potential of cowpea production in generating employment in the area.

This is very important in terms of income generation and commercial activities in the area, a a result of its multiplier effects. Those who get their income either as farmers or labourers will spend such income, which will constitute income to others who will also spend it, and so on. The results further show that, over $25 \%$ of the total labour in cowpea production is absorbed by land preparation; follow by weeding $(23.35 \%)$ and harvesting (19.03\%). The implication is that more than $67 \%$ of labour utilized in cowpea production is absorbed by these three operations.

\section{Capital Inputs in cowpea Production}

Results further show that farmers used both durable and non-durable capital assets. The durable capital include pumps, cutlasses, hoes, axes, sickles and calabashes while the non-durable capital inputs employed include fertilizer, seed and agro-chemical. The study also reveals that about $13 \%$ of the respondents in the study area obtained credit from the formal sources. Farmers in the area 
finance cowpea production from their savings. Only $13 \%$ had access to formal credit provided by their cooperatives. In Nigeria, generally, efforts have been made to reach farmers with formal credit. However, the small-scale farmers have largely been by-passed because, among other problems, they lack the collateral demanded by financial institutions. These categories of farmers are therefore left to their own devices in overcoming capital shortage in their farming operations. Seed used for planting was obtained locally from the market or neighbors. Only few of the respondents used improved variety of planting materials. The study revealed that, the average seed rate used by the farmers in the study area was $17.81 \mathrm{~kg} / \mathrm{ha}$ which is less than $20-25 \mathrm{~kg} / \mathrm{ha}$ recommended for cowpea production system (Wilson and Wilson, 1994). The use of improved seeds could increase yield and returns in the area. Table 5 shows the distribution of farmers according to agrochemical use. As depicted in the table, almost $73.41 \%$ of the respondents used 2 liters of agrochemical per hectare or less, while the remaining used more than 2 liters/ha. Again most of the farmers used agrochemical to control weeds and pest on their farms. The quantities used, however, were generally inadequate. For instance, the average application of agro-chemicals was 1.68 liters/ha which fall short of the recommended 3-4 liters/ha of Weedoff, Sarosite, paraforce, combat, uppercotte and lavaforce respectively, for cowpea (NSADP, 1999). The farmers attributed this problem to the high cost of the chemicals. Most of the weeding was done manually using hoes.

Table 3: Family and non-family labour inputs by operations ( man-days / ha).

\begin{tabular}{|c|c|c|c|c|c|c|}
\hline Operation & $\begin{array}{l}\text { Family man } \\
\text {-day }\end{array}$ & Percentage & $\begin{array}{l}\text { Hired man- } \\
\text { day }\end{array}$ & percentage & $\begin{array}{l}\text { Total man- } \\
\text { day }\end{array}$ & percentage \\
\hline Land prep & 177.25 & 23.75 & 60.75 & 27.04 & 238.00 & 25.17 \\
\hline Planting & 50.30 & 6.73 & 46.00 & 20.48 & 70.78 & 7.49 \\
\hline Chem App & 56.25 & 7.54 & 19.75 & 8.79 & 76.00 & 8.04 \\
\hline Weeding & 180.75 & 24.22 & 40.00 & 17.81 & 220.75 & 23.35 \\
\hline Harvesting & 151.75 & 20.33 & 28.13 & 12.52 & 179.88 & 19.03 \\
\hline Threshing & 130.00 & 17.43 & 30.00 & 13.36 & 160.00 & 16.93 \\
\hline Total & 746.30 & 100.00 & 224.63 & 100.00 & 945.41 & 100.00 \\
\hline
\end{tabular}

Source: field survey, 2013

Table 4: Distribution of farmers according to level of seed use (kg/ ha).

\begin{tabular}{lcc}
\hline Level of Seed & Frequency & Percentage \\
\hline $01-10$ & 48 & 30.38 \\
$11-20$ & 76 & 48.10 \\
$21-30$ & 14 & 08.86 \\
$31-40$ & 09 & 05.70 \\
41 and above & 11 & 0.83 \\
\hline Total & 158 & 100.00 \\
\hline
\end{tabular}

Source: Field survey, 2013

Table 5: Distribution of farmers according to level of agro-chemical use ( $\mathrm{kg} / \mathrm{ha}$ )

\begin{tabular}{lcc}
\hline Level of & Frequency & Percentage \\
Agro-chemical & 116 & 73.41 \\
$01-2$ & 24 & 15.19 \\
$3-4$ & 18 & 11.39 \\
5 and above & 158 & 100.00 \\
\hline Total & &
\end{tabular}

Source: Field survey, 2013

\section{Profitability of cowpea production}

The total cost of production, as indicated in Table 6, was N56, 989.58/ha. The table further reveals that variable cost accounted for $97.31 \%$ of the cost of production, while the fixed cost accounted for less than $3 \%$. This finding agrees with those of Baba et al. (1998), Abduiiahi et al. (2010) and Ojo et al .(2008) who in their separate studies found variable costs accounting for $99 \%, 90.12 \%$ and $92.55 \%$ of the total cost, respectively. That fixed costs accounted for such small proportion of total cost confirms that fixed capital investment in the study area is low. This is expected since the farmers have limited access to credit which would have enabled them to acquire fixed capital inputs for farm expansion. Hence they rely on their savings which are low because of the low incomes. Consequently, they are able to afford only rudimentary tools such as hoes, cutlasses, sickles and the like which are cheap but which could not be relied upon for the needed expansion in cowpea production.

Among the variable costs, the cost of labour input alone constituted 50 percent in cowpea production. The cost of labour was however, dominated by the imputed cost of unpaid family labour which accounted for $53.11 \%$ of the total labour cost (see Table 4). The cost of family labour, although not directly incurred by the farmers was imputed on the assumption that if the farmer and his family had not worked on his farm, they could 
have hired out their labour to other farmers at the prevailing wage rate in the study area. This again, is in agreement with the findings of Baba et al. (1998). In their study in Sokoto State, Nigeria, they reported high level of labour utilization (77\% of total cost of production).

The net farm income in the study area was high N91,361.28/ha, with the rate of return on investment reaching 2.60 which implied that for every $\mathrm{N} 1$ spent by farmer on cowpea production 60 kobo was realized as profit while gross ratio, operating ratio and fixed ratio were $0.61,0.60$ and 0.02 respectively. The entire ratios were less than 1 this indicates that cowpea farming is highly profitable and has great potential for increasing rural income. The high NFI recorded in the area is not only because of effective exploitation of available human and material resources but also because of better marketing prospects of cowpea. This finding is in line with those of Abdullahi et al. (2010), Omonona et al. (2005), Abba (2005), Ojo et al (2008) and Edeh and Igberi (2009) Omolehin et al. (2011) who recorded a high positive financial returns to arable farming .

Table 6: Cost and returns associated with cowpea production (N/ha).

\begin{tabular}{lccc} 
Item & Cost & Percentage & Returns \\
\hline Gross Revenue (GR) & & & $\mathbf{1 4 8 , 3 5 0 . 8 6}$ \\
Variable costs (VC) & $\mathbf{5 5 , 4 5 8 . 3 8}$ & $\mathbf{9 7 . 3 1}$ & 4.56 \\
Seeds & $2,600.66$ & 21.63 \\
Agrochemical & $12,329.12$ & & 34.00 \\
Family labour & & 26.71 \\
(opportunity cost) & $19,377.40$ & 2.63 & 1.72 \\
Hired labour & $15,222,70$ & 6.05 \\
Rent on land & $1,500.00$ & $\mathbf{2 . 6 9}$ & \\
Maintenance/repairs & 978.50 & 2.69 & \\
Marketing/transp cost & 3,450 & & $\mathbf{9 2 , 8 9 2 . 4 8}$ \\
Fixed cost (FC) & $\mathbf{1 , 5 3 1 . 2 0}$ & & $\mathbf{9 1 , 3 6 1 . 2 8}$ \\
Depreciation on farm tools & $1,531.20$ & & $\mathbf{0 . 5 1}$ \\
& & & $\mathbf{0 . 4 6}$ \\
Total cost (TC) & $\mathbf{5 6 , 9 8 9 . 5 8}$ & & $\mathbf{0 . 0 5}$ \\
Gross Margin & & & $\mathbf{2 . 6 0}$ \\
Net Farm Income (NFI) & & & \\
Gross ratio & & & \\
Operation ratio & & & \\
Fixed ratio & & & \\
Return on capital investment & & & \\
\end{tabular}

\section{Source: Field survey, 2013}

\section{Factors Affecting Profitability of Cowpea Production.}

The results of the regression analysis that was used in the determination of the factors that affect profitability of cowpea production in the study area are presented in Table 7. Exponential function was chosen as the leading equation on the basis of $\mathrm{R}^{2}$ value, $\mathrm{t}$ - value, $\mathrm{F}$ - value as well as the signs on the estimated parameters. The result gave an $\mathrm{R}^{2}$ value of $0.81 \%$. This implies that $81 \%$ of variation in profitability of rice production was explained by the variables included in the model.

Table 7 Regression analysis results of cowpea.

\begin{tabular}{lcc}
\hline Variable & Coefficient & T-Value \\
\hline Constant & 6.848229 & $11.77^{* * * *}$ \\
Farm size $\left(\mathrm{X}_{1}\right)$ & 0.9936196 & $13.32^{* * *}$ \\
Labour $\left(\mathrm{X}_{2}\right)$ & -0.1201845 & $-0.96^{\text {NS }}$ \\
Capital $\left(\mathrm{X}_{3}\right)$ & 0.1122579 & $2.91^{* * *}$ \\
Seed cost $\left(\mathrm{X}_{4}\right)$ & -0.2022276 & $-2.91^{* * *}$ \\
Agro-chemical $\left(\mathrm{X}_{5}\right)$ & 0.1661571 & $2.46^{* *}$ \\
R2 & 0.81 & \\
F-Value & $131.59^{* * *}$ &
\end{tabular}

Note $* * *, * *$ and NS implies statistically significant at $1 \%, 5 \%$ levels and Not Significant, respectively.

Source: Field survey (2013).

The coefficient of agro-chemical was significant at $(\mathrm{P}<0.05)$, farm size and capital and seed were significant at $(\mathrm{P}<0.01)$ respectively while the coefficient of labour was negative and not significant indicating the input do 
not significantly influence profit level of the farmers. Moreover, the negative and significant coefficients of the variable seed imply that increase in the quantities of these inputs would result in decrease profitability of the farm enterprise. implication of positive and significant coefficient of farm size and capital and agro-chemical is that, farmers with high capital base have ability or tendency to afford or purchase production input like agrochemical and also expand their farm size which could result in increase in production and this will tend to increase their profit level. This result is in agreement with that of Abduiiahi et al. (2010) who observed that amount of capital inputs per farm determines the level of investment in such a farm.

\section{Production function Analysis}

The production function that was used to determine the nature of inputs - output relationship in cowpea production is presented in Table 8 (Double $\log$ production function as the lead equation). The value of coefficient of determinations $\left(\mathrm{R}^{2}\right)$ indicated that $66 \%$ of the variation in output of cowpea production was explained by the inputs included in the production model. The regression coefficients of land size $\left(\mathrm{X}_{1}\right)$, labour $\left(\mathrm{X}_{2}\right)$, capital $\left(\mathrm{X}_{3}\right)$ and agro-chemical $\left(\mathrm{X}_{5}\right)$ were positive indicating that an increase in these inputs, holding others constant will lead to an increase in the gross output. The result also showed that land size $\left(\mathrm{X}_{1}\right)$, capital $\left(\mathrm{X}_{3}\right)$ and agro-chemical $\left(\mathrm{X}_{5}\right)$ were significant at $1 \%$, level of probability while labour $\left(\mathrm{X}_{2}\right)$ was significant at $5 \%$ level of probability. But the coefficient of seed $\left(\mathrm{X}_{4}\right)$ was negative and not significant.

Table 8 Estimate of Cobb-douglas production function for maize production

\begin{tabular}{lcl}
\hline Variable & Coefficient & T-Value \\
\hline Constant & 10.3286 & $68.35^{* * *}$ \\
Land $\left(\mathrm{X}_{1}\right)$ & 0.7713114 & $8.88^{* * *}$ \\
Labour $\left(\mathrm{X}_{2}\right)$ & 0.0000397 & $2.10^{* *}$ \\
capital $\left(\mathrm{X}_{3}\right)$ & 0.0000907 & $2.64^{* * *}$ \\
Seed $\left(\mathrm{X}_{4}\right)$ & -0.000033 & $-1.38^{\mathrm{NS}}$ \\
Agro-chemical $\left(\mathrm{X}_{5}\right)$ & 0.0001159 & $2.69^{* * *}$ \\
R2 & 0.66 & \\
F-Value & $58.88^{* * *}$ & \\
\hline
\end{tabular}

Note $* * *, * *$ and NS implies statistically significant at $1 \%, 5 \%$ levels and Not Significant, respectively. Source: Field survey (2013).

\section{Efficiency of resource used in cowpea production.}

The result of the economic efficiency of resource use based on the ratios of marginal value product (MVP) to marginal factor cost (MFC) showed that land $\left(\mathrm{X}_{1}\right)$, labour $\left(\mathrm{X}_{2}\right)$,capital $\left(\mathrm{X}_{3}\right)$ and agro-chemical $\left(\mathrm{X}_{4}\right)$ were underutilized (Table 9). The marginal value products (MVPS) of the entire variable were positive implying that using more of those resources would increase the total value product. The MVP for land was $\$ 1870.12$ implying that increasing land by 1 unit would increase total value product (TVP) by $\$ 1870.12$, if other inputs are held constant. The marginal factor cost (MFC) for land was $\$ 780.5$, which was lower than the MVP. Hence, land was being used below economic optimum level. Therefore, increasing the area cultivated would increase profit. .With respect to labour, the MVP was $\$ 2165$. Implying that increasing labour input by 1 man-day would increase TVP by $\$ 2165$, if other inputs are held constant. The MFC of labour was $\$ 1300$ which was lower than the MVP. This implies that labour input was being used below economic optimum level. Therefore, cowpea farmers could increase their level of profit by increasing labour. Also for capital, the MVP was $¥ 1802.18$. Implying that increasing capital input by 1 unit would increase TVP by $\$ 1802.18$, if other inputs are held at constant. The MFC of capital was $\$ 1620$ which was lower than the MVP, which implies that capital input was being used below economic optimum level. Therefore, cowpea farmers could increase their level of profit by increasing capital.

The MVP for agro-chemical was $\$ 1119.3$, which implies that increasing agro-chemical by 1 liter would increase TVP by $¥ 1119.3$, if other inputs are held constant. The MFC of agro-chemical was $\$ 900$, which was lower than the MVP. This implies that agro-chemical input was being used below economic optimum level. Therefore the cowpea farmers could increase profit by increasing agro-chemical input So, increasing the quantities of the four inputs in cowpea production in Agricultural zone 1 will increase cowpea output and in turn increase cowpea revenue in the study area. This finding is in agreement with those of Abdullahi et al. (2010) and Ojo et al. (2008) who in separate studies found that resources like land, Labour, seed and fertilizer are underutilized, so increase in quantity of these inputs would lead to increase in revenue status of the farmers. 
Economics of cowpea production under small-scale cowpea enterprise...

Table 9 Efficiency of resource use in cowpea production

\begin{tabular}{lcccc}
\hline Variables & MPP & MVP & MFC & $\begin{array}{c}\text { Efficiency } \\
\text { ratio }\end{array}$ \\
\hline Land $\left(\mathrm{X}_{1}\right)$ & & & 780 & 2.40 \\
Labour $\left(\mathrm{X}_{2}\right)$ & $20,779.12$ & 1870,12 & 1300 & 1,67 \\
Capital $\left(\mathrm{X}_{3}\right)$ & 4.33 & 2165 & 1620 & 1.11 \\
Agro-chem $\left(\mathrm{X}_{5}\right)$ & 3,59 & 1802.18 & 900 & 1,24 \\
\hline
\end{tabular}

Source: field survey, 2013

\section{Conclusion}

The study revealed that inspite of the abundant potentials of cowpea production in the study area, available resources were not fully tapped. The respondents in the area were generally small-scale farmers that depended on small but scattered plots they acquire through inheritance. Land, labour, capital and purchased inputs like seeds and agro-chemicals were the main production factors influencing cowpea production in the study area; cowpea producers in the study area possess a lot of agricultural know-how, skill and expertise in farming under difficult conditions and constraints.

The study also showed that cowpea production in the study area was profitable. This means that the area has great potential to increase cowpea production and farmer's income, if effort are made for the widespread adoption of new technologies and identified constraint are addressed. The study showed that farm size, capital and agro-chemical were important in explaining the variation in profitability of cowpea producers in the study area. The findings also revealed that the marginal value product for the inputs was more than their marginal factor cost signifying that they are used below economic optimum level

\section{Policy Implications}

In view of the current global effort in achieving the Millennium Development Goals (MDGs), Nigeria as a part of this effort should as a matter of fact integrate within the present presidential initiatives on agriculture transformation agenda, a food policy measure that will strategically ensure that cowpea farmers follow appropriate farm practices in the course of technology adoption. In this regard, a more realistic package that will increase the ratio of the number of farmer to extension contact should be encouraged as a vital step towards increased cowpea production in Niger State in particular and in Nigeria at large. Similarly, the Farmers in the study area need to form cooperatives to improve accessibility to improved inputs such as improved seed, agrochemicals and institutional credit. The adoption of such inputs could be further encouraged through a more effective extension services. There is urgent need for feeder roads to facilitate transportation of product to the market from rural areas. Also this will ensure efficient dissemination and utilization of the technology at the grassroot level.

\section{References}

[1]. Abdullahi, A, K.M.Baba and A.L. Ala(2010), Economics of Resource use in small-scale rice production: A case study of Niger State, Nigeria. International journal of AgriScience, 2(5) : 429-443

[2]. Abba.M.W (2005) .Economics of cowpea production in Adamawa State of Nigeria. Russian Journal of Agricultural and SocioEconomic Sciences, 1(13):60-65.

[3]. Alamu . J.F (2002). Comparative analysis of maize/legume intercropping system in Sabon

[4]. Gari Local Government Area, Zaria, Kaduna State. Nigerian Journal of Sustainable

[5]. Tropical Agricultural Research, 4: 87-93.

[6]. Araka, S (1990). Developing World Agriculture, London: Macmillan.

[7]. Baba, K.M, L.A. Okosun and D. Mohammed (1998). Promoting agricultural resource use and farm incomes through small-scale irrigation ;A case study in Sokoto State. Nigerian Journal of Rural Sociology, 2: $21-28$.

[8]. $\quad$ Dzemo, W.D., Niba, A.S and J.A.N Asiwe.(2010) .African Journal of Biological Technology. 9(11):1673-1679.

[9]. Edeh .H.O. and C.O. Igberi (2009). Assessment of vegetable cowpea production among smallholder farmers in Ohaukwu local government area of Ebonyi State, Nigeria. ARPN Journal of Agricultural and Biological Science. 7(3):215-222.

[10]. FAOSTAT. (2000). Site internet : http//www. Fao. org/statistics

[11]. FAOSTAT (2006). faostat.fao.org/site/567/DesktopDefault.aspx?PageID=567. Accessedon 31st December, 2006.

[12]. Food and Agriculture Organization (FAO) (2011). Agricultural Production Status world wide sites pages. http, www.fao.org/Faostat.

[13]. Fasasi A.R. (2007). "Technical Efficiency in Food Crop Production in Oyo State, Nigeria", Journal of Human Ecology, 22(3): 245249

[14]. Gulati, A (2000). Globalization,World Trade Organization and food security, Emerging Issues A and Options Journal of International Agriculture 39(4): 342-356.

[15]. Harwood, R.R. (1987). "Low input technologies for sustainable agricultural system". Sustainable Agricultural system. In Ruttan, V.W and C.E. pray (Eds.) westived press Boulder, Colorado. PP 41-59.

[16]. Levin, C.A (1984). The role of credit in the transportation of traditional agriculture. Nigerian Journal of Economics and Social Studies, 6(12):27-30.

[17]. National Population Commission (NPC) (2006). Provisional Census Figures, Federal Government of Nigeria P.15.

[18]. NSADP (Niger State Agricultural Development Project) (1999). Impact study final report, Minna, Nigeria 128 PP.

[19]. Niger State Agricultural Development Project (NSADP)(2012).An Insight in to Agricultural Activities in Niger State MANR P.5. 
[20]. Njoku, J.E (1991). Factor influencing the adoption of improve oil palm production technologies by small holders in Imo State Nigeria. PP 207 - 218 In: Olukosi J.O., A.O. Ogungbile and B.A. Kalu (eds). Appropriate Agricultural Technology for Resource Poor Farmers. A publication of the Nigerian National Farming System Research Network

[21]. Obeta, M.E and E.C Nwagbo (1990). The adoption of agricultural innovations in Nigeria.

[22]. A case study of an improved IITA technology pakage in Anambra State. In: Olukosi,

[23]. J.O, A.O. Ogungbile and B.A Kulu (eds) Appropriate Agricultural Technologies for Resource Poor Farmers. A publication of Nigerian National Farming Systems Research Network, PP. 231-245.

[24]. Odebode, S.O (2007). Gender participation of melon farmers in Ibaropa Area of Oyo State, Nigeria. Agricultural Journal 2(1): 108-111.

[25]. Ojo, M. A., U. S. 1Mohammed, A.O. Ojo, E. S. Yisa and J. H. Tsado. (2009). Profit efficiency of small scale cowpea farmers in Niger state, Nigeria. International Journal of Agricultural Economics and Rural Development.2(2):40-48.

[26]. Olayide, S.O and E.O.Heady (1982). Introduction to Agricultural Production Economics. University Press Ibadan. 319PP.

[27]. Omonona B.T. , O.A. Egbetokun and A.T. Akanbi. (2005). Farmers resource - use and technical efficiency in cowpea production in Nigeria. Economic Analysis and Policy.40 (1):87-95.

[28]. Omolehin.R.A, S.S.Adeola, B. Ahmed, E.O.Ebukiba and O.B.Adeniji. (2011). Economics of insecticides usage among cowpea farmers in Kaduna State, Nigeria. American Journal of Experimental Agriculture .1(4): 353-362.

[29]. Roger, E.M and F.F Shoemaker (2001) Diffusion of Innovations. Fourth Edition free press, New York, U. S. A 345 PP.

[30]. Singh, B.B, Ehlers, J.D., Sharma, B., Freire, Filho, F.R. (2002). Recent progress in cowpea breeding. In: Fatokun, Tarawali, C.A, Singh, S.A, B.B., Kormawa, P.M.,Tamo,M (Eds), Challenges and opportunityfor enhancing sustainable cowpea production. Proceedings of world cowpea conference III held at IITA, Ibadan, Nigeria.

[31]. Wilson, R . I and M.P Wilson (1994). Training in Mangrove Rice Production ( WARDA) Colorcraft, Hong Kong Publishers 254 PP.

[32]. World Bank (1992). A strategy to develop agriculture in sub-Saharan Africa region. Washington DC, USA. PP. 67-69. 